\title{
Wydarzenie w konteście polsko-czeskich kontaktów naukowych (I Kongres Czechoznawstwa Polskiego - Od Szczecina do Cieszyna, jesień 2016 r.) ${ }^{1}$
}

Kiedy w 2006 r. zostało powołane do życia Polsko-Czeskie Towarzystwo Naukowe z siedzibą we Wrocławiu (dalej też PCzTN), zarówno w gronie jego czołowych przedstawicieli, jak też wśród stosunkowo licznie wstępujących w szeregi Towarzystwa członków dominowało przekonanie, że oto otwierają się szeroko nowe możliwości wspólnego działania na polu polsko-czeskich i czesko-polskich kontaktów naukowych. Atmosfera, która temu towarzyszyła, odzwierciedlała niewątpliwie podniosłość i odświętność chwili, ale również rozmaite oczekiwania i nadzieje, które wiązali z przyszłością nowo powstałego Towarzystwa poszczególni jej członkowie i przedstawiciele.

Po dynamicznym początkowym okresie funkcjonowania Polsko-Czeskiego Towarzystwa Naukowego - zarówno pod względem podejmowanych inicjatyw, częstotliwości posiedzeń zarządu po obu stronach granicy czy też rozwoju liczbowego bazy członkowskiej, zaczęly poniekąd przejawiać się pewne niespójności w odniesieniu do wytyczanych kolejnych planów działania i ich realizacji. Ponadto uwidoczniły się mniej lub bardziej naturalne podziały czy też profilujące się grupy zgodnie z reprezentowanymi przez poszczególnych członków dziedzinami nauki oraz ośrodkami badawczymi, wśród których obok Wrocławia - jako siedziby towarzystwa - ambicje posiadania własnych przedstawicielstw dotyczyły zwłaszcza Poznania, Opola czy Brna.

\footnotetext{
1 Pierwotna czeska wersja niniejszego sprawozdania została opublikowana w biuletynie Instytutu Historii Czeskiej Akademii Nauk w Pradze (Česko-polská védecká spolupráce a I. kongres polských bohemistických studií, Bulletin Historického ústavu Akademie věd České republiky (2017), s. 17-20; zob. też Przegląd Uniwersytecki, nr 2 (217), 2017, s. 34-36.
} 
Coroczna organizacja walnych zgromadzeń (na przemian w Polsce i Republice Czeskiej), współorganizowanie licznych polsko-czeskich konferencji, (współ) wydawanie publikacji naukowych (zwłaszcza z dziejów Ziemi Kłodzkiej i polsko-czeskich stosunków) - to wszystko razem było zdaniem niemałej liczby członków i sympatyków Towarzystwa jednak zbyt mało, biorąc pod uwagę potencjał ludzki i znaczenie tej organizacji w kręgu badaczy zainteresowanych dalszym rozwojem polsko-czeskich kontaktów naukowych. Cały ten barwny i różnorodny etap - od pierwotnego dynamicznego i wielostronnego rozwoju przez ścieranie się różnych idei, poglądów i koncepcji aż po nazwijmy to stabilizację działań bez jednoczesnego podejmowania nowych wyzwań - streszcza niewielka objętościowo, lecz cenna materiałowo i źródłowo publikacja Polsko-Czeskie Towarzystwo Naukowe / Polsko-česká védecká společnost / Polish-Czech Scientific Society. Informatorium, Wrocław 2015.

Walne zgromadzenie we wchodnioczeskim Hradcu Králové, mieście związanym różnymi wątkami także z dziejami Polski - że przywołamy chociażby postać czeskiej i polskiej królowej (stąd nazwa miasta) Elżbietę Ryksę, córkę Przemysła II Wielkopolskiego i Ryksy szwedzkiej, internowanie polskich powstańców styczniowych czy udział Wojska Polskiego w operacji Dunaj co miało miejsce w 2015 r., oznaczało przełom w dziejach Towarzystwa (szerzej: R. Baron, Valné shromáždèní Polsko-české védecké společnosti a védecký seminár Česká polonica a glacensia, Bulletin Historického ústavu AV ČR, (2016), s. 39-40). Nowo wybrany Zarząd, na czele którego stanął dotychczasowy wiceprezes dr. Ryszard Gładkiewicz z Uniwersytetu Wrocławskiego, zaczął bezzwłocznie oraz intensywnie działać na rzecz przygotowania I Kongresu Czechoznawstwa Polskiego. Myśl zwołania kongresu polskich badaczy, zajmujących się szeroko rozumianymi dziejami czeskiego narodu, języka, kultury, prawa, geografii itd., zrodziła się już co prawda znacznie wcześniej i prymat w tym zakresie należy niewątpliwie do prof. Jacka Balucha z Uniwersytetu Jagiellońskiego w Krakowie - wybitnego polskiego bohemisty, a zarazem byłego ambasadora w Czechosłowacji i Republice Czeskiej - jednak z różnych względów ten jak najbardziej słuszny postulat pozostawał wciąż na etapie planów długookresowych.

Zadania przygotowania kongresu miał się podjąć nowo ustanowiony Komitet Programowo-Organizacyjny w następującym składzie: dr Ryszard Gładkiewicz (przewodniczący), prof. Jacek Baluch (wiceprzewodniczący), prof. Adam Jezierski (wiceprzewodniczący, prorektor Uniwersytetu Wrocławskiego), mgr Jadwiga Dunaj (wiceprzewodniczącza ds. finansowych) Julian Golak (wiceprzewodniczący, przedstawiciel władz samorządowych Województwa Dolnośląskiego oraz Stowarzyszenia Solidarność Polsko-Czesko-Słowacka), prof. Irena Korbelářová (wiceprzewodniczą- 
cza, przedstawicielka strony czeskiej, wiceprzewodnicząca PCzTN, Uniwersytet Śląski w Opawie), dr Roman Baron (współpraca czesko-polska, sekretarz i czeski koordynator PCzTN, Instytut Historii Czeskiej Akademii Nauk), dr Janusz Gołaszewski (współpraca z archiwami, dyrektor Archiwum Państwowego we Wrocławiu), prof. Joanna Goszczyńska (współpraca z literaturoznawcami, dyrektor Instytutu Slawistyki Zachodniej i Uniwersytetu Wrocławskiego), prof. Zbigniew Greń (współpraca ze środowiskiem warszawskim, dziekan Wydziału Polonistyki Uniwersytetu Warszawskiego), Arkadiusz Ignasiak (konsul honorowy Republiki Czeskiej we Wrocławiu), Mirosław Jasiński (towarzyszący program kulturalny, m.in. były dyrektor Instytutu Polskiego w Pradze), prof. Zenon Jasiński (program w Województwie Opolskim, wiceprzewodniczący PCzTN, długoletni dyrektor Instytutu Nauk Pedagogicznych Uniwersytetu Opolskiego), prof. Zdzisław Latajka (współpraca z przedstawicielami nauk przyrodniczych, były rektor Uniwersytetu Wrocławskiego), dr hab. Petr Mrkývka (konsul honorowy RP w Brnie), prof. Jan Rychlík (współpraca czesko-polska, Uniwersytet Karola w Pradze), dr hab. Damian Szymczak (program w Województwie Wielkopolskim, Uniwersytet im. Adama Mickiewicza w Poznaniu), prof. Wojciech Świątkiewicz (współpraca w środowisku śląskim, dyrektor Instytutu Socjologii Uniwersytetu Śląskiego w Katowicach), Igor Wójcik (pełnomocnik Marszałka Województwa Dolnośląskiego ds. kontaktów z Republiką Czeska).

Od razu przystąpiono do działań: odbywało się jedno spotkanie robocze za drugim, miał miejsce szereg konsultacji, narad bilateralnych i multilateralnych na różnych szczeblach i w różnym gronie osób; przede wszystkim jednak regularnie zbierał się wyżej wymieniony Komitet oraz Zarząd PCzTN (prawie wszyscy jego członkowie brali udział w pracach Komitetu), których głównymi partnerami zostali przedstawiciele Uniwersytetu Wrocławskiego - rektor Marek Bojarski i prorektor Adam Jezierski. Do zasadnicznych posiedzeń należały obrady z wiceministrem Szkolnictwa, Młodzieży i Sportu Republiki Czeskiej Jaroslavem Fidrmucem (Praga, 20 X 2015), prorektorem Uniwersytetu im. Adama Mickiewicze w Poznaniu Zbigniewem Pilarczykiem (Poznań, 14 XII 2015), a zwłaszcza z rektorem Uniwersytetu Wrocławskiego M. Bojarskim (Wrocław, 25 I 2016). Kolejne posiedzenia Komitetu i Zarządu PCzTN (Praga, 22 IV 2016; Poznań, 28 IV 2016; Pilzno 17 V 2016) zmierzały przede wszystkim w kierunku uszczegółowienia koncepcji całego kongresu, zapewnienia niezbędnych środków finansowych oraz nadania ostatecznej wersji programowi.

24 X 2016 r. w przepięknej barokowej sali (Oratorium marianum) nowo wybrany rektor Uniwersytetu Wrocławskiego, prof. Adam Jezierski, uroczyście zagaił centralną część I Kongresu Czechoznawstwa Polskiego. W krótkim, ale 
jakże dobitnym, treściwym i inspirującym przemówieniu zwrócił m.in. uwagę na wkład czeskiej nauki i kultury w rozwój Uniwersytetu Wrocławskiego, śląskiej metropolii i całego Śląska jako integralnej części regionu Europy Środkowej. Aczkolwiek rektor Jezierski jest z zawodu i powołania chemikiem, zebrał liczne brawa i oklaski przepełnionej sali jako świetny mówca, a na dodatek muzyk, kiedy na organach zagrał m.in. humoreski Antonína Dvořáka.

Znaczenie kongresu dla Republiki Czeskiej i wzajemnej czesko-polskiej współpracy potwierdził samą już swoją obecnością, ale również wyraził to przekonanie słowami dr Jakub Karfík - ambasador RCz w Warszawie. Dodajmy, iż ambasador RP w Pradze, prof. Grażyna Bernatowicz, spotkała się z organizatorami kongresu następnego dnia, i to w ramach dyskusji panelowej zatytułowanej Perspektywy polsko-czeskich stosunków.

Z ogólną koncepcją i programem tzw. sieciowego kongresu czechoznawstwa polskiego - podkreślmy to raz i mocno: w ogóle pierwszego tego typu i tej rangi przedsięwzięcia naukowego w szerokim kontekście kontaktów polsko-czeskich, zapoznał obecnych podczas uroczystego zagajenia dr Ryszard Gładkiewicz - przewodniczący Polsko-Czeskiego Towarzystwa Naukowego i zarazem główny organizator kongresu.

Wstępne referaty wygłosili czołowi badacze: prof. Jacek Baluch z Uniwersytetu Jagiellońskiego w Krakowie (Czechoznawstwo jako perspektywa i horyzont badaw$c z y$ ), prof. Jaroslav Pánek z Instytutu Historii Czeskiej Akademii Nauk w Pradze, obecnie również dyrektor Czeskiego Instytutu Historycznego w Rzymie (Polskie czechoznawstwo - charakter $i$ sens jednego kierunku badawczego, zob. Ziemia Kłodzka, 11-12/2016, nr 268-269, s. 38-40), prof. Józef Dobosz, dyrektor Instytutu Historii Uniwersytetu im. Adama Mickiewicza z Poznaniu (U zarania stosunków polsko-czeskich - Dobrawa i Mieszko, współautorka referatu dr Marzena Matla) oraz prof. Jan Miodek z Uniwersytetu Wrocławskiego (Polacy i Czesi a język). Chociaż pod względem merytorycznym i metodologicznym poszczególne wystąpienia w niejednym aspekcie się różniły, to wszyscy razem nakreślili szeroki zakres problemów badawczych bezpośrednio związanych z teorią i praktyką polskich badań czechoznawczych. Nawiasem mówiąc, polski termin „czechoznawstwo” jest praktycznie nieprzetłumaczalny na język czeski (tytułem przykładu por. Ziemia Kłodzka, 11-12/2016, nr 268-269, s. 3, gdzie mowa jest o „čechovědectví”).

Dalsze dwudniowe obrady kongresowe przebiegały w poszczególnych sekcjach w różnych miejscach historycznego centrum Wrocławia (nie tylko w murach uniwersyteckich, ale np. również w kawiarni „Literacka“ w Rynku): I. Stan i perspektywy bohemistyki w Polsce (dyskusja panelowa, gestorzy: prof. Dobrochna 
Dabert-Bakuła, prof. Joanna Goszczyńska i prof. Zbigniew Greń), II Dzieje Czech i stosunków polsko-czeskich w oczach historyków polskich u progu XXI w., część 1 - do końca XVIII w., część 2 - XIX-XXI w. (dyskusja panelowa, gestorzy: prof. Antoni Barciak, dr hab. Jan Jacek Bruski, prof. Józef Dobosz, prof. Rościsław Żerelik), III Czechy w polskiej publicystyce i thumaczeniach (dyskusja panelowa, gestor: prof. Jacek Baluch), IV (została odwołana, zmieniając się w samodzielną konferencję politologiczna), V Przetomowe wydarzenia historyczne we wspótczesnych polskich i czeskich podręcznikach szkolnych (seminarium i debata publiczna, gestorzy: prof. Danuta Konieczka-Śliwińska, prof. Blažena Gracová, prof. Grażyna Pańko), VI Kościót polski i czeski po II wojnie światowej (dyskusja panelowa, gestor: Tomasz Dostatni OP), VII Czechy i Czesi w działalności bibliotek (warsztaty, gestor: Andrzej Tyws), VIII Koncepcja polsko-czeskiego i czesko-polskiego stownika terminologii prawnicznej (warsztaty, gestorzy: dr Andrzej Huchla, dr hab. Petr Mrkývka). W obradach poszczególnych sekcji brali udział czołowi polscy badacze - zwłaszcza w dziedzinie humanistyki; zajmowali przy tym różne role: moderatorów, uczestników paneli dyskusyjnych czy autorów przyczynków dyskusyjnych. Tytułem przykładu wymieńmy chociaż uczestników drugiej, czyli historycznej sekcji: prof. prof. Wojciech Iwańczak, Henryk Gmiterek, Marek Cetwiński, Andrzej Małkiewicz, dr hab. dr hab. Krzysztof Nowak, Sławomir Nowinowski czy Stanisław Pijaj. Co warto w tym miejscu podkreślić, kongres nie obył się bez więcej aniżeli symbolicznego udziału przedstawicieli nauki czeskiej - w tej liczbie czeskich polonistów i polonoznawców.

W ostatnim (trzecim) dniu kongresu miało miejsce jego uroczyste zakończenie, które przebiegało w zabytkowej sali gotyckiego Starego Ratusza. Pierwszym punktem programu była prezentacja dwu obszernych monografii zbiorowych dotyczących polonoznawsta czeskiego, które wydał Instytut Historii Czeskiej Akademii Nauk jako wynik projektów Czesko-Polskiego Forum przy Ministerstwie Spraw Zagranicznych Republiki Czeskiej (szerzej: R. Baron, R. Madecki, Slavnostní prezentace kolektivních monografii zamèrených na česká bádáni o Polsku, Bulletin Historického ústavu AV ČR [2016], s. 64-66). Dr R. Baron przedstawił treść obu powiązanych ze sobą publikacji oraz podziękował wszystkim, którzy przyczynili się do ich wydania - szczególnie zaś dr. Romanowi Madeckiemu z Uniwersytetu im. Masaryka w Brnie, dyrektorowi Studium Europy Wschodniej Uniwersytetu Warszawskiego dr. Janowi Malickiemu, a także dyrektor Instytutu Historii Czeskiej Akademii Nauk prof. Evie Semotanovej.

Następnie wysłuchano szczegółowych sprawozdań i relacji na temat przebiegu i wyników poszczególnych sekcji, które przedstawili ich gestorzy. Z ramienia Mi- 
nisterstwa Spraw Zagranicznych RP głos zabrała mgr Marzena Krajewska (obecnie już radca Ambasady RP w Pradze). Podsumowania trzydniowych obrad we Wrocławiu w imieniu strony czeskiej podjał się prof. J. Pánek, który podziękował również organizatorom sieciowego kongresu za wyjątkowo pozytywny wynik ich starań i zabiegów, w pierwszej kolejności zaś prezesowi PCzTN Ryszardowi Gładkiewiczowi oraz Jadwidze Dunaj z Zarządu tegoż towarzystwa. W imieniu strony polskiej przemówili były i obecny prezes PCzTN, tzn. prof. J. Baluch i dr R. Gładkiewicz, dziękując wszystkim współpracownikom oraz obecnym czeskim uczestnikom i współorganizatorom: prof. prof. Irenie Korbelářovej, Jaroslavowi Pánkowi, Janowi Rychlíkowi, Rudolfowi Žáčkowi, Ondřejowi Felcmanowi, Naděždzie Morávkovej i wielu innym. Główna część I Kongresu Czechoznawstwa Polskiego w ten oto sposób dobiegła do satysfakcjonującego uczestników końca.

Należy bowiem dodać, iż nieodłączną częścią składową sieciowego kongresu były nie tylko te centralne obrady we Wrocławiu, ale także liczne konferencje przebiegające w wielu innych miastach od Szczecina (Pomorze, Szczecin, Bałtyk w relacjach polsko-czesko-stowackich, gestorzy: prof. Anna Szczepańska-Dudziak, prof. Paweł A. Leszczyński, 12 1X 2016) przez Poznań (Wspótpraca naukowa Poznania i Brna - rekonesans, perspektywy, gestorzy: dr hab. Damian Szymczak, prof. Anna Gawarecka, 12-13 X 2016), Opole (ogólnopolski konkurs dla młodzieży Co wiemy o historii i kulturze naszych południowych sasiadów - Czechów, gestor: prof. Zenon Jasiński, wrzesień - listopad 2016) i Olesno (O czeskiej kulturze i historii, gestorzy: prof. Zenon Jasiński, starosta oleski Stanisław Belka, 10 X 2016), aż po znajdujące się na pograniczu polsko-czeskim miasta jak Prudnik (Szkota i edukacja regionalna na pograniczu polsko-czeskim, gestorzy: prof. Zenon Jasiński, starosta prudnicki Radosław Roszkowski, burmistrz Franciszek Fejdych, 6 X 2016), Wałbrzych (Gospodarka, turystyka, edukacja akademicka na pograniczu sudeckim, zamek Ksiąz, 14 XI 2011), Stonawę na Zaolziu (Dzieje i recepcja filozofii czeskiej w polsko-czeskich relacjach kulturalnych, gestorzy: dr hab. Andrzej Kasperek, dr hab. Marek Rembierz, 11 X 2016) i Cieszyn (Kapitat społeczny i kulturowy polsko-czeskiego pogranicza na Ślasku Cieszyńskim - dokonania, problemy, perspektywy, gestorzy: prof. Halina Rusek, prof. Ewa Ogrodzka-Mazur, dr Józef Szymeczek, 18 X 2016).

Ostatnia z wymienionego cyklu konferencji kongresowych odbyła się w Cieszynie (Obraz Czech, Czechów i relacji polsko-czeskich w mediach polskich i czeskich, gestorzy: prof. Wojciech Świątkiewicz, dr hab. Andrzej Kasperek, mgr Bogdan Kasperek z Euroregionu Śląsk Cieszyński, burmistrz Cieszyna Ryszard Macura, dr Józef Szymeczek, 25 XI 2016); pod koniec - niejako symbolicznie - 
R. Gładkiewicz wystąpił z referatem pod wiele mówiącym tytułem Podsumowanie I Kongresu Czechoznawstwa Polskiego - pierwsze doświadczenia i refleksje zwiąane z przygotowaniem kongresu.

Nie podejmując w tym miejscu próby własnej oceny przebiegu i znaczenia całego kongresu, wypadnie nam jednak stwierdzić, iż Polsko-Czeskie Towarzystwo Naukowe z siedzibą we Wrocławiu stanęło na wysokości zadania: najpierw przyjmując wyzwanie zorganizowania pierwszego ogólnopolskiego kongresu czechoznawstwa polskiego, a następnie doprowadzając tę ideę do realizacji, i to na godnym uznania poziomie organizacyjnym i merytorycznym. Wygłoszone referaty, dyskusje panelowe, debaty, przyczynki, kuluarowa wymiana myśli pomiędzy czołowymi polskimi badaczami zajmującymi się Czechami, tzn. przede wszystkim między bohemistami (językoznawcami i literaturoznawcami), historykami, prawnikami, politologami, socjologami, filozofami etc., i to z wielu polskich osrodków naukowych, a także dialog przedstawicieli tego polskiego środowiska naukowego z przybyłymi na poszczególne części kongresu koleżankami i kolegami z Republiki Czeskiej - to wszystko razem stworzyło znaczący fakt dokonany i wartość, którą należy obecnie odpowiednio spożytkować i dalej rozwijać (także w celu przekazania tego dziedzictwa następnym generacjom badaczy na tym polu).

Siłą rzeczy nie wszystko udało się zrealizować tak, jak sobie tego życzyli organizatorzy i uczestnicy - np. wsparcie medialne kongresu było znacząco mniejsze i raczej tylko o zasięgu regionalnym, brakowało bezpośredniej obecności kongresu w tak ważnych ośrodkach polskiego czechoznawstwa jak Kraków czy Warszawa, doszło również do odwołania jednej z sekcji głównych obrad we Wrocławiu. Niemniej - jak zaznaczono powyżej - ogólna ocena kongresu, w którym łącznie wzięło udział około 800 osób, jest bardziej niż przekonująca. Wymowne pod tym względem jest również podpisanie porozumienia o współpracy w przygotowaniach kolejnych kongresów o tym samym charakterze i treści, którą w Sali Senatu Uniwersytetu Wrocławskiego podpisali Jego Magnificencja Rektor Adam Jezierski, Przewodniczący Polsko-Czeskiego Towarzystwa Naukowego Ryszard Gładkiewicz oraz rzecznik generalny Stowarzyszenia Solidarność Polsko-Czesko-Słowacka Julian Golak - w obecności wielu członków zarządu PCzTN i zaproszonych gości (16 I 2017).

Ph.D. Roman Baron,

Historický ústav

Akademie věd České republiky

Prosecká 809/76, 19000 Praha 